\title{
Infraspecific diversity of Beauveria bassiana from India based on DNA microsatellite markers
}

\author{
Agrawal $\mathbf{Y}^{1, *}$, Mual $\mathbf{P}^{1}$, Shenoy $\mathbf{B D}^{1,2, *}$ \\ ${ }^{I}$ Microbial Type Culture Collection and Gene Bank, CSIR-Institute of Microbial Technology, Sector 39-A, Chandigarh \\ - 160 036, India \\ ${ }^{2}$ Present address: CSIR-National Institute of Oceanography, Dona Paula, Goa - 403 004, India \\ "Corresponding authors: E-mail: shenoynio@gmail.com, yaminiagrawal04@gmail.com
}

Agrawal Y, Mual P, Shenoy BD 2014 - Infraspecific diversity of Beauveria bassiana from India based on DNA microsatellite markers. Mycosphere 5(5), 635-645, Doi 10.5943/mycosphere/5/5/4

\begin{abstract}
Beauveria bassiana is an insect-associated fungal species and it is economically important as an environment-friendly mycoinsecticide and a good source of biologically active secondary metabolites. In this study, we employed DNA microsatellite markers to investigate the infraspecific diversity of 102 isolates of B. bassiana sensu stricto from India. All the microsatellite markers were easily amplifiable for all the isolates and provided a good genotype resolution. The microsatellite analysis indicated the presence of highly polymorphic, randomly distributed populations of $B$. bassiana with variable host range and apparently no host-specificity. We, however, observed region-wise clustering of the populations within B. bassiana sensu stricto from India.
\end{abstract}

Keywords - allelic diversity - biocontrol - genetic diversity - host relationships - insectpathogenic fungi - polymorphism

\section{Introduction}

Beauveria bassiana (Bals.-Criv.) Vuill. includes mainly fungal pathogens of phylogenetically diverse insect-hosts; however, some isolates survive and thrive as endophytes, epiphytes and saprobes (Ownley et al. 2010, Roy et al. 2010). This species, as delimited in traditional taxonomy, has been found to include multiple morphologically-similar phylogenetic species (Rehner et al. 2006). It is also known that B. bassiana sensu lato has a clonal genetic structure (Meyling et al. 2009) and the isolates belonging this taxon are believed to be generalist pathogens, apparently lacking host-specificity, probably the geographical distribution influencing their pathogenic behaviour (Bidochka et al. 2002, Wang et al. 2003, Rehner \& Buckley 2005, Meyling et al. 2009). The studies related to the role of ecological factors such as habitat and hosts relationships on population structure of B. bassiana indicate at effect of habitat selection but varied relationships of associated hosts, highlighting the importance of ecological factors and geographical origin on B. bassiana isolates (Bidochka et al. 2002, Wang et al. 2003).

It is known that microsatellite regions can distinguish closely related microbial entities and reveal population genetic structure (Avise 2004, Enkerli \& Widmer 2010) of a fungal species. Isolation and characterization of microsatellite markers have already been reported for a variety of 


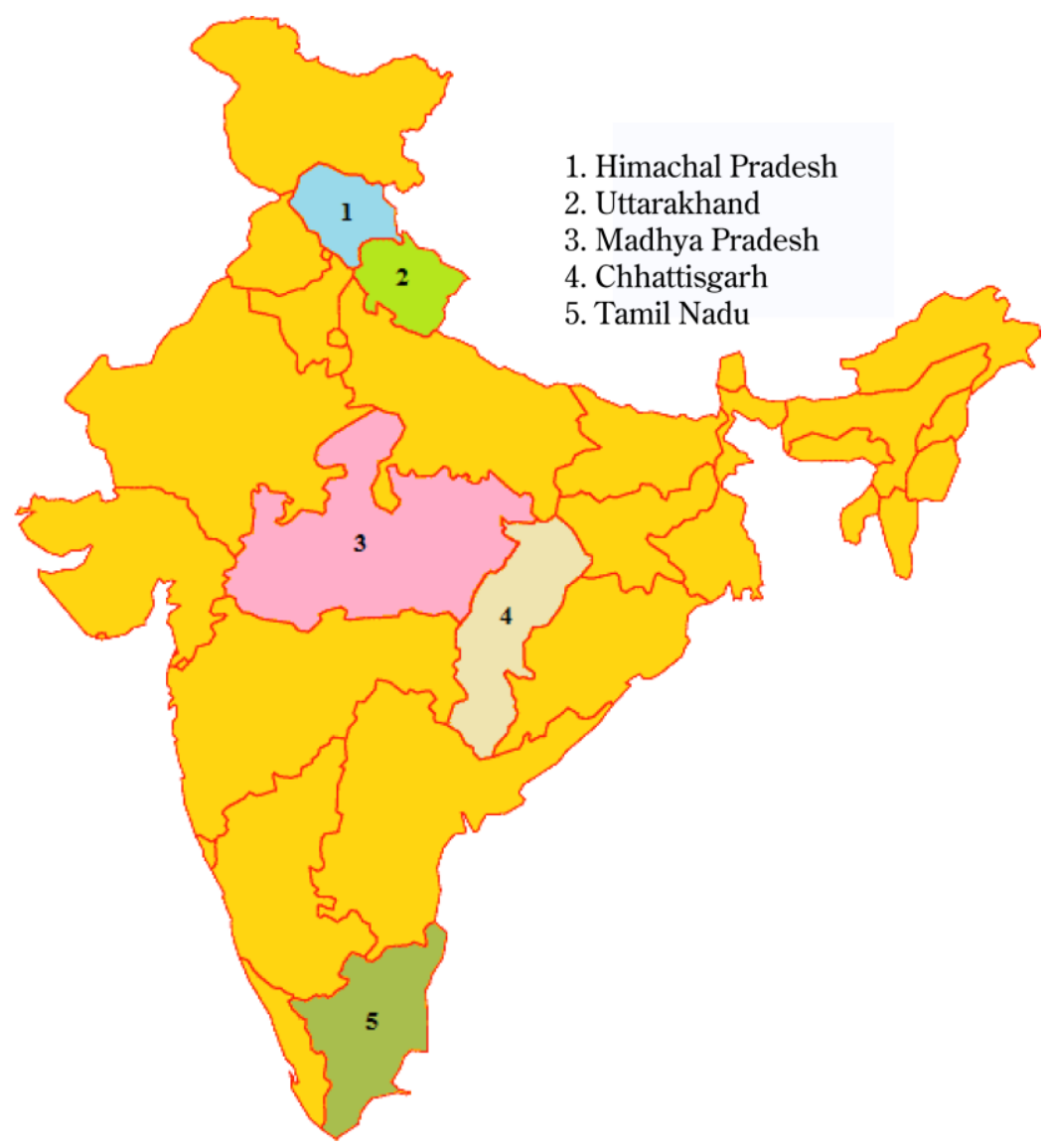

Fig. 1 - Site locations of Beauveria bassiana isolates included in the study (marked 1-5)

entomopathogenic fungi, including B. bassiana sensu lato (Rehner \& Buckley 2003, Meyling et al. 2009), B. brongniartii (Enkerli et al. 2001), Metarhizhium anisopliae (Enkerli et al. 2005, Oulevey et al. 2009), Paecilomyces fumosoroseus (Dalleau-Clouet et al. 2005) etc. Regardless the extensive studies on mycoinsecticide potential, host specificity, virulence and pathology of B. bassiana from Indian region (Haraprasad et al. 2001, Devi et al. 2008, Challa et al. 2013), fundamental understanding related to its ecology, genetic diversity, population biology and species delimitation is limited from India (Devi et al. 2006).

We, therefore, aimed clarify if the above observation is applicable to the B. bassiana sensu stricto isolates from India. To achieve this, we employed microsatellite markers as they have been used in previous studies to reveal the infraspecific diversity in B. bassiana sensu lato (Rehner \& Buckley 2003, Meyling et al. 2009).

\section{Materials \& methods}

\section{Fungal isolates and DNA isolation}

A collection of 102 B. bassiana isolates (Table 1) were included in this study. The site locations of these isolates have been mapped in Fig. 1. Isolates were grown on potato dextrose agar (PDA, HiMedia) and incubated at $25{ }^{\circ} \mathrm{C}$ for 5-8 days. These were preserved as glycerol stocks prepared from fresh mycelia or harvested conidia in $10 \%$ glycerol and stored at $-70{ }^{\circ} \mathrm{C}$. The genomic DNA was extracted from fresh mycelia using ZR Fungal/ Bacterial DNA isolation kit (Catalogue number D6005, Zymo Research, USA). The quality and concentration of DNA extracted was assessed by $0.8 \%$ agarose gel electrophoresis and Nanodrop Spectrophotometer ND1000 (Thermo Scientific, USA). 
Table 1 List of $B$. bassiana isolates under study and their general details

\begin{tabular}{|c|c|c|c|c|}
\hline S. No. & Strain & Culture location & Host/Substrate & Host Order \\
\hline 1 & MTCC 984 & ATCC, USA & NA & $\overline{\mathrm{NA}}$ \\
\hline 2 & MTCC 3653 & Jogendra Nagar, Mandi, HP & $\begin{array}{l}\text { Oak tasar silkworm } \\
\text { pupae }\end{array}$ & Lepidoptera \\
\hline 3 & MTCC 4105 & Maneri, Mandla, MP & Hyblaea puera & Lepidoptera \\
\hline 4 & MTCC 4106 & Gosalpur, Jabalpur, MP & Grasshopper & Orthoptera \\
\hline 5 & MTCC 4107 & Gosalpur, Jabalpur, MP & Grasshopper & Orthoptera \\
\hline 6 & MTCC 4108 & Gosalpur, Jabalpur, MP & Crop beetle & Coleoptera \\
\hline 7 & MTCC 4109 & Kanger, Bastar, Chhattisgarh & Black ant & Hymenoptera \\
\hline 8 & MTCC 4110 & Mandla, MP & Eutectona machaeralis & Lepidoptera \\
\hline 9 & MTCC 4111 & Bijadandi, Jabalpur, MP & small black ant & Hymenoptera \\
\hline 10 & MTCC 4120 & Pariyat, Jabalpur, MP & Hyblaea puera & Lepidoptera \\
\hline 11 & MTCC 4121 & Udaipur, Mandla, MP & Pieris rapae & Lepidoptera \\
\hline 12 & MTCC 4122 & Tikariya, Mandla, MP & Beetle & Coleoptera \\
\hline 13 & MTCC 4492 & Katni, MP & Pieris rapae & Lepidoptera \\
\hline 14 & MTCC 4495 & Katni, MP & Hyblaea puera & Lepidoptera \\
\hline 15 & MTCC 4496 & Katni, MP & Grasshopper & Orthoptera \\
\hline 16 & MTCC 4497 & Katni, MP & Crop beetle & Coleoptera \\
\hline 17 & MTCC 4498 & Balaghat, MP & Eutectona machaeralis & Lepidoptera \\
\hline 18 & MTCC 4499 & Balaghat, MP & Beetle & Coleoptera \\
\hline 19 & MTCC 4500 & Balaghat, MP & Black ant & Hymenoptera \\
\hline 20 & MTCC 4501 & Balaghat, MP & Grub & Coleoptera \\
\hline 21 & MTCC 4503 & Betul, MP & Plusia orichalcea & Lepidoptera \\
\hline 22 & MTCC 4504 & Betul, MP & NA & NA \\
\hline 23 & MTCC 4505 & Betul, MP & NA & NA \\
\hline 24 & MTCC 4506 & Betul, MP & Beetle & Coleoptera \\
\hline 25 & MTCC 4507 & Betul, MP & Beetle & Coleoptera \\
\hline 26 & MTCC 4508 & Betul, MP & Beetle & Coleoptera \\
\hline 27 & MTCC 4509 & Betul, MP & Eutectona machaeralis & Lepidoptera \\
\hline 28 & MTCC 4510 & Betul, MP & Eutectona machaeralis & Lepidoptera \\
\hline 29 & MTCC 4511 & Betul, MP & Eutectona machaeralis & Lepidoptera \\
\hline 30 & MTCC 4512 & Betul, MP & Eutectona machaeralis & Lepidoptera \\
\hline 31 & MTCC 4513 & Betul, MP & Hyblaea puera & Lepidoptera \\
\hline 32 & MTCC 4514 & Hoshangabad, MP & Hyblaea puera & Lepidoptera \\
\hline 33 & MTCC 4515 & Hoshangabad, MP & Hyblaea puera & Lepidoptera \\
\hline 34 & MTCC 4516 & Betul, MP & Beetle & Coleoptera \\
\hline 35 & MTCC 4517 & Betul, MP & Hyblaea puera & Lepidoptera \\
\hline 36 & MTCC 4528 & Chhindwara, MP & Plusia orichalcea & Lepidoptera \\
\hline 37 & MTCC 4529 & Betul, MP & Plusia orichalcea & Lepidoptera \\
\hline 38 & MTCC 4530 & Betul, MP & Plusia orichalcea & Lepidoptera \\
\hline 39 & MTCC 4531 & Betul, MP & Plusia orichalcea & Lepidoptera \\
\hline 40 & MTCC 4532 & Hoshangabad, MP & Hyblaea puera & Lepidoptera \\
\hline 41 & MTCC 4533 & Hoshangabad, MP & Hyblaea puera & Lepidoptera \\
\hline 42 & MTCC 4534 & Hoshangabad, MP & Hyblaea puera & Lepidoptera \\
\hline 43 & MTCC 4535 & Hoshangabad, MP & Eutectona machaeralis & Lepidoptera \\
\hline 44 & MTCC 4536 & Hoshangabad, MP & Black ant & Hymenoptera \\
\hline 45 & MTCC 4537 & Hoshangabad, MP & Eutectona machaeralis & Lepidoptera \\
\hline 46 & MTCC 4538 & Hoshangabad, MP & Eutectona machaeralis & Lepidoptera \\
\hline 47 & MTCC 4539 & Hoshangabad, MP & Eutectona machaeralis & Lepidoptera \\
\hline 48 & MTCC 4540 & Hoshangabad, MP & Eutectona machaeralis & Lepidoptera \\
\hline 49 & MTCC 4542 & Chhindwara, MP & Eutectona machaeralis & Lepidoptera \\
\hline
\end{tabular}




\begin{tabular}{|c|c|c|c|c|}
\hline S. No. & Strain & Culture location & Host/Substrate & Host Order \\
\hline 50 & MTCC 4543 & Chhindwara, MP & Eutectona machaeralis & Lepidoptera \\
\hline 51 & MTCC 4544 & Chhindwara, MP & Eutectona machaeralis & Lepidoptera \\
\hline 52 & MTCC 4546 & Chhindwara, MP & Plusia orichalcea & Lepidoptera \\
\hline 53 & MTCC 4547 & Chhindwara, MP & Fruit fly & Diptera \\
\hline 54 & MTCC 4548 & Chhindwara, MP & Plusia orichalcea & Lepidoptera \\
\hline 55 & MTCC 4549 & Mandla, Chhattisgarh & Black ant & Hymenoptera \\
\hline 56 & MTCC 4550 & Seoni, MP & Eutectona machaeralis & Lepidoptera \\
\hline 57 & MTCC 4551 & Seoni, MP & Eutectona machaeralis & Lepidoptera \\
\hline 58 & MTCC 4552 & Mandla, Chhattisgarh & Beetle & Coleoptera \\
\hline 59 & MTCC 4553 & Seoni, MP & Eutectona machaeralis & Lepidoptera \\
\hline 60 & MTCC 4554 & Seoni, MP & Eutectona machaeralis & Lepidoptera \\
\hline 61 & MTCC 4557 & Mandla, Chhattisgarh & Eutectona machaeralis & Lepidoptera \\
\hline 62 & MTCC 4559 & Mandla, Chhattisgarh & Eutectona machaeralis & Lepidoptera \\
\hline 63 & MTCC 4560 & Mandla, Chhattisgarh & Eutectona machaeralis & Lepidoptera \\
\hline 64 & MTCC 4562 & Mandla, Chhattisgarh & Fly & Diptera \\
\hline 65 & MTCC 4563 & Mandla, Chhattisgarh & unidentified insect & NA \\
\hline 66 & MTCC 4564 & Mandla, Chhattisgarh & Beetle & Coleoptera \\
\hline 67 & MTCC 4565 & Jabalpur, MP & Plusia orichalcea & Lepidoptera \\
\hline 68 & MTCC 4566 & Jabalpur, MP & Plusia orichalcea & Lepidoptera \\
\hline 69 & MTCC 4567 & Jabalpur, MP & Plusia orichalcea & Lepidoptera \\
\hline 70 & MTCC 4568 & Jabalpur, MP & Plusia orichalcea & Lepidoptera \\
\hline 71 & MTCC 4569 & Jabalpur, MP & Plusia orichalcea & Lepidoptera \\
\hline 72 & MTCC 4571 & Mandla, Chhattisgarh & Eutectona machaeralis & Lepidoptera \\
\hline 73 & MTCC 4572 & Mandla, Chhattisgarh & Eutectona machaeralis & Lepidoptera \\
\hline 74 & MTCC 4575 & Jabalpur, MP & Eutectona machaeralis & Lepidoptera \\
\hline 75 & MTCC 4576 & Jabalpur, MP & Eutectona machaeralis & Lepidoptera \\
\hline 76 & MTCC 4577 & Jabalpur, MP & Eutectona machaeralis & Lepidoptera \\
\hline 77 & MTCC 4578 & Jabalpur, MP & Eutectona machaeralis & Lepidoptera \\
\hline 78 & MTCC 4579 & Jabalpur, MP & Eutectona machaeralis & Lepidoptera \\
\hline 79 & MTCC 4580 & Jabalpur, MP & Insect & NA \\
\hline 80 & MTCC 4581 & Jabalpur, MP & Plusia orichalcea & Lepidoptera \\
\hline 81 & MTCC 4582 & Jabalpur, MP & Plusia orichalcea & Lepidoptera \\
\hline 82 & MTCC 4599 & Shahdol, MP & Beetle & Coleoptera \\
\hline 83 & MTCC 4600 & Shahdol, MP & Plusia orichalcea & Lepidoptera \\
\hline 84 & MTCC 4605 & Shahdol, MP & Beetle & Coleoptera \\
\hline 85 & MTCC 6095 & Mandla,MP & Eutectona machaeralis & Lepidoptera \\
\hline 86 & MTCC 6097 & Mandla,MP & Eutectona machaeralis & Lepidoptera \\
\hline 87 & MTCC 6098 & Mandla,MP & Eutectona machaeralis & Lepidoptera \\
\hline 88 & MTCC 6099 & Mandla,MP & Eutectona machaeralis & Lepidoptera \\
\hline 89 & MTCC 6100 & Mandla,MP & Eutectona machaeralis & Lepidoptera \\
\hline 90 & MTCC 6286 & Mandla,MP & Eutectona machaeralis & Lepidoptera \\
\hline 91 & MTCC 6287 & Mandla,MP & Eutectona machaeralis & Lepidoptera \\
\hline 92 & MTCC 6288 & Mandla,MP & Eutectona machaeralis & Lepidoptera \\
\hline 93 & MTCC 6289 & Mandla,MP & Eutectona machaeralis & Lepidoptera \\
\hline 94 & MTCC 6291 & Dantewada, Chhattisgarh & Hyblaea puera & Lepidoptera \\
\hline 95 & MTCC 6297 & Dantewada, Chhattisgarh & Hyblaea puera & Lepidoptera \\
\hline 96 & MTCC 6298 & Bastar, Chhattisgarh & Eutectona machaeralis & Lepidoptera \\
\hline 97 & MTCC 6341 & Mandla, MP & Eutectona machaeralis & Lepidoptera \\
\hline 98 & MTCC 6685 & Dindigul, Tamil Nadu & Soil & NA \\
\hline 99 & MTCC 6779 & Dindigul, Tamil Nadu & Field infected larva & NA \\
\hline 100 & MTCC 7689 & Dindigul, Tamil Nadu & Field infected larva & NA \\
\hline
\end{tabular}




\begin{tabular}{cllll}
\hline S. No. & Strain & Culture location & Host/Substrate & Host Order \\
\hline $\mathbf{1 0 1}$ & MTCC 7690 & Dindigul, Tamil Nadu & Soil & NA \\
$\mathbf{1 0 2}$ & MTCC 9348 & US Nagar, Uttarakhand & Ideoscopus clypealis & Hemiptera \\
\hline
\end{tabular}

\# MTCC denotes to Microbial Type Culture collection; NA: Information not available; MP: Madhya Pradesh; HP: Himachal Pradesh

\section{Microsatellite typing}

A set of eight previously described microsatellite markers (Rehner \& Buckeley 2003) were used (Table 2) for the microsatellite typing. Touchdown polymerase chain reaction (PCR) was performed to amplify the microsatellite-containing-loci from genomic DNA. The PCR reactions were carried out in an Eppendorf Mastercycler with following cycling parameters: initial denaturation at $95{ }^{\circ} \mathrm{C}$ for 2 minutes followed by 10 cycles of denaturation at $94{ }^{\circ} \mathrm{C}$ for 30 seconds, annealing at $66{ }^{\circ} \mathrm{C}$ for 30 seconds and further reduction in annealing temperature by $1{ }^{\circ} \mathrm{C}$ at each succeeding cycle, and extension at $72{ }^{\circ} \mathrm{C}$ for 1 minute. Then, 36 cycles of 30 seconds at $56{ }^{\circ} \mathrm{C}$ and 1 minute at $72{ }^{\circ} \mathrm{C}$ and a final extension at $72{ }^{\circ} \mathrm{C}$ for 30 minutes was done at the end of the PCR amplification and the reaction was held at $4{ }^{\circ} \mathrm{C}$ until further processed. The resulting microsatellite amplicons were resolved on $4 \%$ Tris-Borate-EDTA agarose gels stained with ethidium bromide $(0.5 \mu \mathrm{g} / \mathrm{ml})$ and visualized under UV light.

\section{Microsatellite data analysis}

Identity version 1.0 (Wagner \& Sefc 1999) was used for microsatellite data analysis and generating allele frequency and null allele frequency. The presence and absence of different alleles over each locus was scored as binary data comprising of 1 and 0 , respectively. A binary matrix was prepared containing allele information for cluster analysis. The microsatellite binary matrix was imported into TREECON (Van de peer \& De Wachter 1994) for further analysis. An Unweighted Pair Group Method with Arithmetic Mean (UPGMA) dendrogram was constructed following Nei and Li index (Nei \& Li 1979) with 1000 bootstrap replicates (Felsenstein 1985). Simpson's index of diversity (D) was used to calculate the discriminatory power of microsatellite markers to ensure whether any two randomly selected isolates belong to same genotype for a given (combination of) marker(s). A ' $D$ ' value of ' 1 ' designates all isolates to be different whereas a ' $D$ ' value of 0 designates all isolates to be identical.

\section{Results}

All microsatellite markers used in this study were found to be polymorphic, displaying up to 55 (Ba02 locus) allelic frequencies. The estimated frequency of null alleles was in the range of 0.01-0.04 for all the markers, except $\mathrm{Ba} 01$ locus which depicted high frequency of null allele, i.e., 0.46 (Table 2). Also, the Ba01 locus was found to be least polymorphic, with the amplification of 15 alleles (Table 2). This marker, therefore, was found to be least informative in the present population structure analysis. The discriminatory powers for individual markers ranged from 0.9901 to 0.9905 (Table 3). The ' $\mathrm{D}$ ' value for combined panel of all markers was found to be 0.8563 (Table 3). This represents unrelated and polymorphic alleles among the B. bassiana isolates from this study.

Table 2 Microsatellite data of 102 Beauveria bassiana isolates using 8 Loci (Identity1.0)

\begin{tabular}{cccc}
\hline Locus & $\begin{array}{c}\text { Repeat } \\
\text { motif }\end{array}$ & $\begin{array}{c}\text { No. of alleles, } \\
\text { size Range (bp) }\end{array}$ & $\begin{array}{c}\text { Estimated frequency of } \\
\text { null alleles (\%) }\end{array}$ \\
\hline Ba01 & $(\mathrm{CA})_{14}$ & $15(78-115)$ & 46 \\
Ba02 & $(\mathrm{CA})_{20}$ & $55(93-178)$ & 1 \\
Ba03 & $(\mathrm{CA})_{26}$ & $50(112-162)$ & 1 \\
Ba05 & $(\mathrm{GAT})_{15}$ & $43(88-178)$ & 3 \\
Ba06 & $(\mathrm{GTT})_{10}$ & $43(92-117)$ & 2 \\
Ba08 & $(\mathrm{AGG})_{10}$ & $47(168-250)$ & 2 \\
Ba12 & $(\mathrm{CTT})_{7}$ & $43(135-224)$ & 4 \\
Ba13 & $(\mathrm{AAG})_{9}$ & $44(135-213)$ & 3 \\
\hline
\end{tabular}


Table 3 Discriminatory power (D) of individual markers and the complete set of 8 markers

\begin{tabular}{llll}
\hline Marker & D & Complete Set & D \\
\hline $\mathrm{Ba} 01$ & 0.9903 & Complete marker set & 0.8563 \\
$\mathrm{Ba} 02$ & 0.9901 & & \\
$\mathrm{Ba} 03$ & 0.9903 & & \\
$\mathrm{Ba} 05$ & 0.9904 & & \\
$\mathrm{Ba} 06$ & 0.9905 & & \\
$\mathrm{Ba} 08$ & 0.9904 & & \\
$\mathrm{Ba} 12$ & 0.9904 & & \\
$\mathrm{Ba} 13$ & 0.9904 & & \\
\hline
\end{tabular}

The unrooted UPGMA tree based on microsatellite data for all the populations is presented in Fig. 2. The tree separated the populations into five clusters (Cluster I to Cluster V). However, the UPGMA dendrogram based on the combined microsatellite data revealed no apparent correlation among the genotype of the isolates, host-substrate and geographical location (Fig. 2). It represented high allelic diversity among $B$. bassiana isolates from this study.

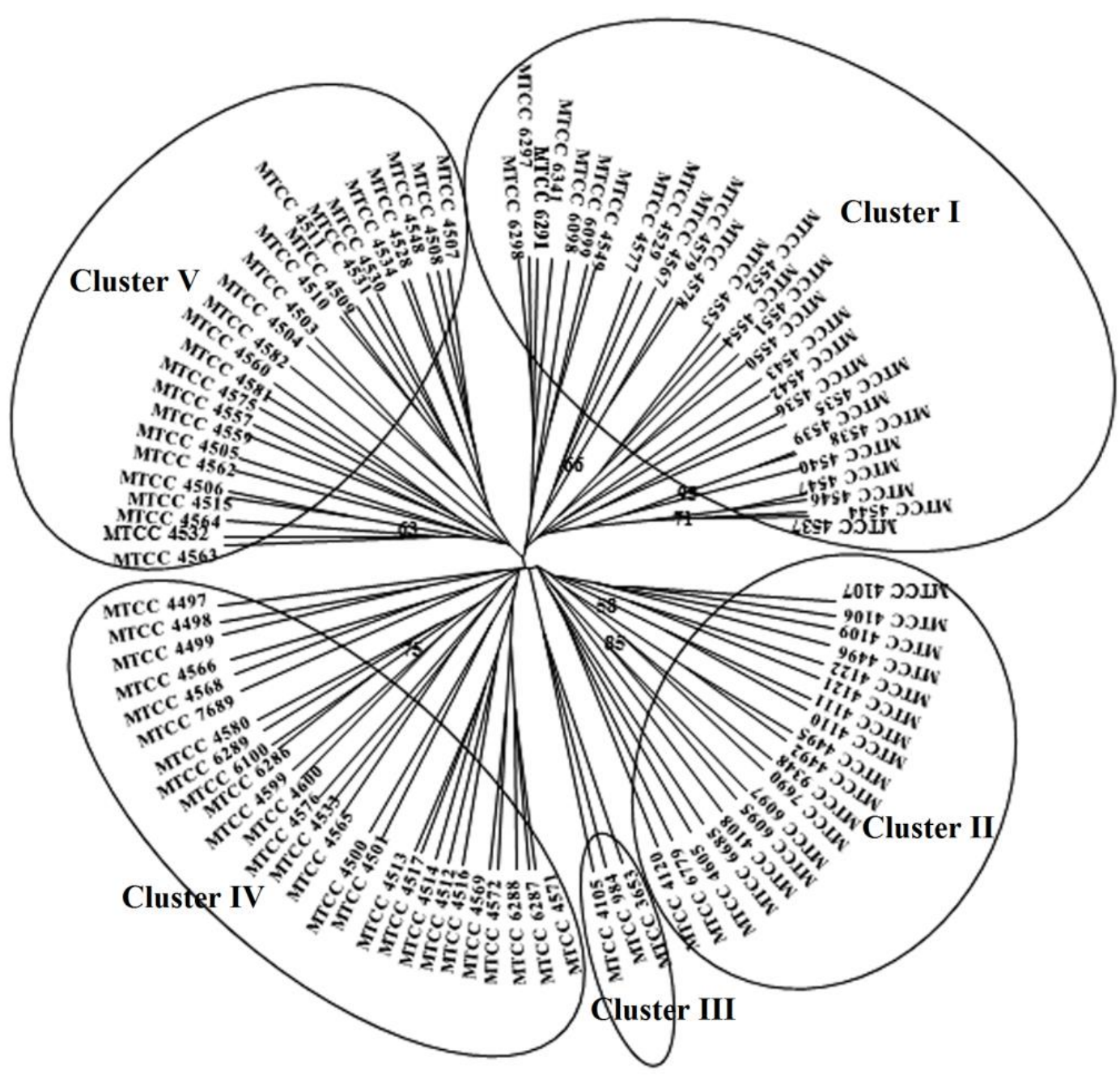

Fig. 2 - UPGMA Cluster analysis. Split tree prepared using TREECON software representing the genetic correlations of all combined 102 B. bassiana isolates from India. Bootstrap values above $50 \%$ are highlighted 


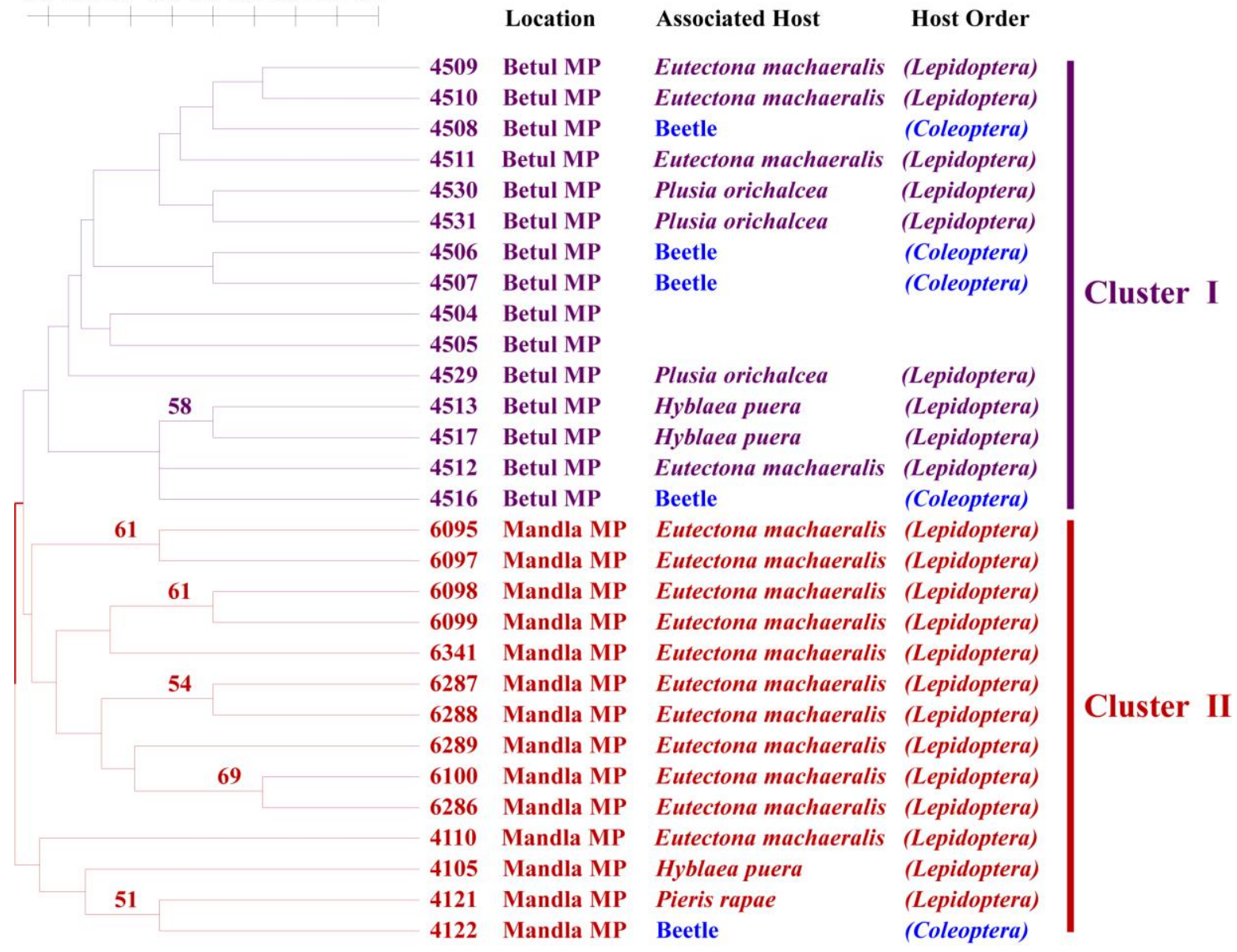

Fig. 3 - UPGMA Cluster analysis representing region-wise genetic correlations of Betul and Mandla (from Madhya Pradesh population site) origins of B. bassiana isolates from India. Bootstrap values above $50 \%$ are highlighted.

We then looked into reduced datasets with locality related origin (Betul vs. Mandla) or host related association (Eutectona machaeralis vs. Plusia orichalcea) (Figs. 3, 4). UPGMA cluster analysis was performed for these reduced datasets as already described for the combined microsatellite data. Two of the branches obtained in unrooted UPGMA dendrogram of Betul vs. Mandla subpopulations were identified as a distinct genetic cluster and designated as cluster I and II (Fig. 3). These two branches were significantly clustered on the basis of their location Betul and Mandla in the present dataset. However, there were no regular arrangements of favored host (Lepidoptera or Coleoptera) in each of the two clusters I and II. Similarly, in the host based reduced dataset, no grouping was found. A mixture of two hosts was observed in each cluster (Fig. 4). So, any evidence for host-wise selection was lacking from the B. bassiana isolates in this study from India.

\section{Discussion}

The microsatellite markers have revealed very high genetic diversity and polymorphic population structure in $B$. bassiana sensu stricto from India. This result is comparable to the earlier studies employing microsatellite loci for depiction of genetic diversity of B. bassiana (Fernandes et al. 2006, Takatsuka 2007, Meyling et al. 2009, 2012, Castrillo et al. 2010, Yao et al. 2012). The microsatellite markers provided a good genotype resolution, indicating that all selected isolates belong to B. bassiana sensu stricto (Meyling et al. 2012). The relationships of B. bassiana genotypes with its associated host were proposed to be accidental co-occurrence of such host associated population structure for B. bassiana, which were supported to be primarily habitat associated rather than host associated (Bidochka et al. 2002). 


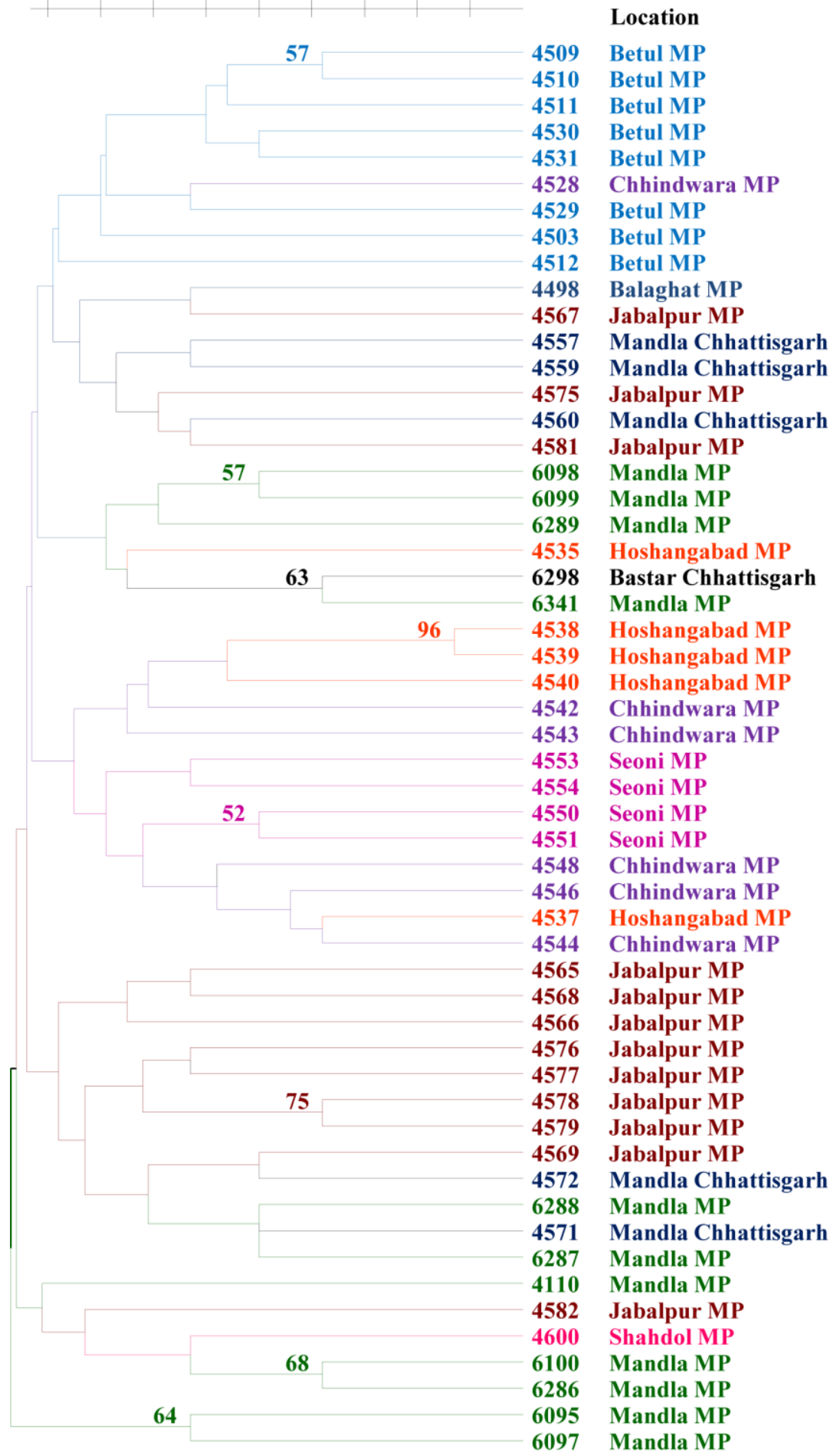

Associated Host Host Order

Eutectona machaeralis (Lepidoptera) Eutectona machaeralis (Lepidoptera) Eutectona machaeralis (Lepidoptera) Plusia orichalcea (Lepidoptera) Plusia orichalcea (Lepidoptera) Plusia orichalcea (Lepidoptera) Plusia orichalcea (Lepidoptera) Plusia orichalcea (Lepidoptera) Eutectona machaeralis (Lepidoptera) Eutectona machaeralis (Lepidoptera) Plusia orichalcea (Lepidoptera)

Eutectona machaeralis (Lepidoptera) Eutectona machaeralis (Lepidoptera) Eutectona machaeralis (Lepidoptera) Eutectona machaeralis (Lepidoptera) Plusia orichalcea (Lepidoptera) Eutectona machaeralis (Lepidoptera) Eutectona machaeralis (Lepidoptera) Eutectona machaeralis (Lepidoptera) Eutectona machaeralis (Lepidoptera) Eutectona machaeralis (Lepidoptera) Eutectona machaeralis (Lepidoptera) Eutectona machaeralis (Lepidoptera) Eutectona machaeralis (Lepidoptera) Eutectona machaeralis (Lepidoptera) Eutectona machaeralis (Lepidoptera) Eutectona machaeralis (Lepidoptera) Eutectona machaeralis (Lepidoptera) Eutectona machaeralis (Lepidoptera) Eutectona machaeralis (Lepidoptera) Eutectona machaeralis (Lepidoptera) Plusia orichalcea (Lepidoptera) Plusia orichalcea (Lepidoptera) Eutectona machaeralis (Lepidoptera) Eutectona machaeralis (Lepidoptera) Plusia orichalcea (Lepidoptera) Plusia orichalcea (Lepidoptera) Plusia orichalcea (Lepidoptera) Eutectona machaeralis (Lepidoptera) Eutectona machaeralis (Lepidoptera) Eutectona machaeralis (Lepidoptera) Eutectona machaeralis (Lepidoptera) Plusia orichalcea (Lepidoptera) Eutectona machaeralis (Lepidoptera) Eutectona machaeralis (Lepidoptera) Eutectona machaeralis (Lepidoptera) Eutectona machaeralis (Lepidoptera) Eutectona machaeralis (Lepidoptera) Plusia orichalcea (Lepidoptera) Plusia orichalcea (Lepidoptera) Eutectona machaeralis (Lepidoptera) Eutectona machaeralis (Lepidoptera) Eutectona machaeralis (Lepidoptera) Eutectona machaeralis (Lepidoptera)

Fig. 4 - UPGMA Cluster analysis representing host-wise genetic correlations of Eutectona machaeralis and Plusia orichalcea hosts of B. bassiana isolates from India. Bootstrap values above $50 \%$ are highlighted

We further checked for more reduced datasets based on their geographical locations. Figs. 5 and 6 represent region-wise genetic correlations of Madhya Pradesh and Chhattisgarh reduced datasets, and of Tamil Nadu (Southern-India) with other parts of India (MP, HP and Chhattisgarh). We could clearly observe the region-wise clustering for all these reduced datasets, which signifies the greater role of geographical locations (ecological factors) rather than host-pathogen interactions for $B$. bassiana sensu stricto isolates from India. 


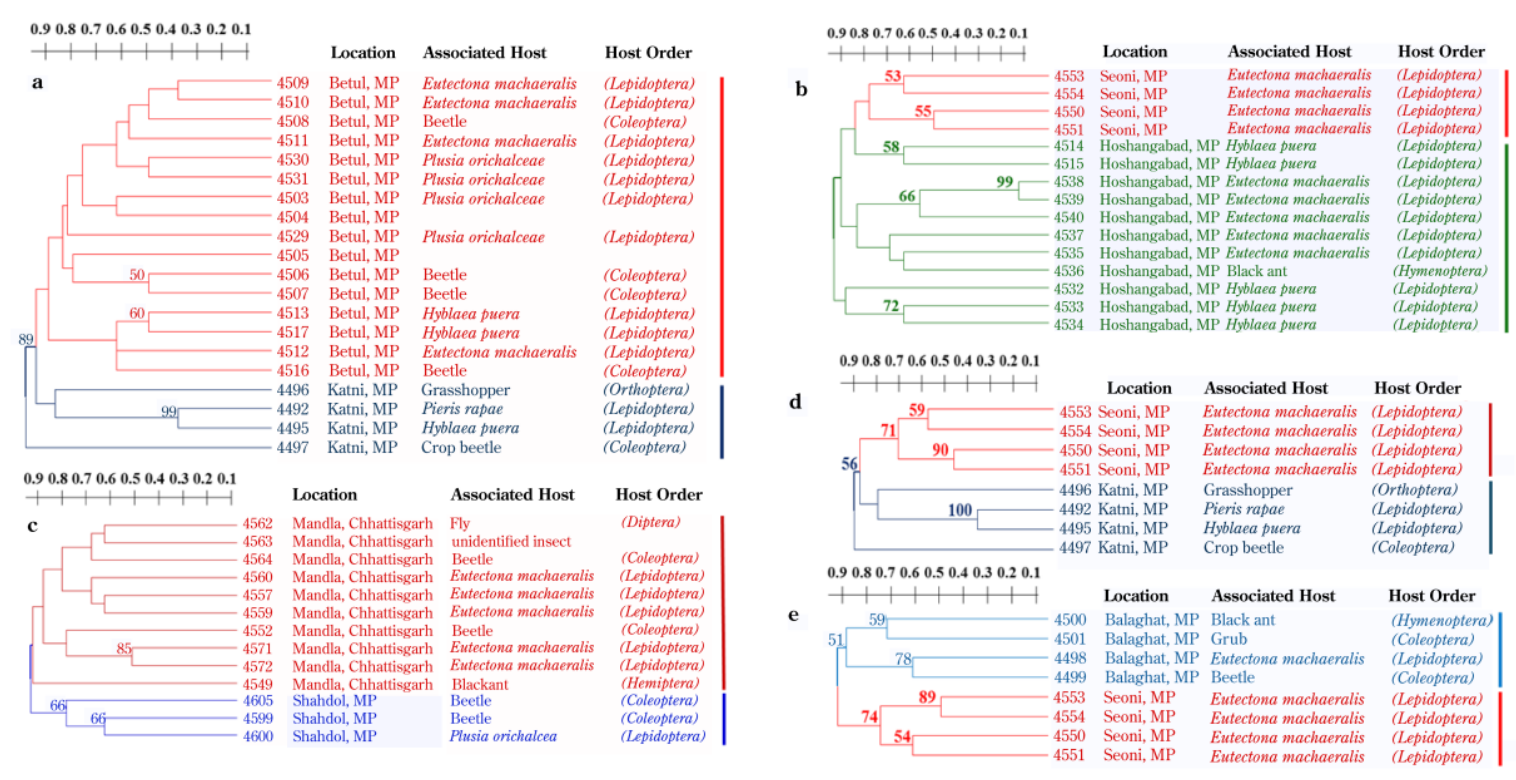

Fig. 5 - Region-wise genetic correlations of MP and Chhattisgarh reduced datasets. Bootstrap values above $50 \%$ are highlighted
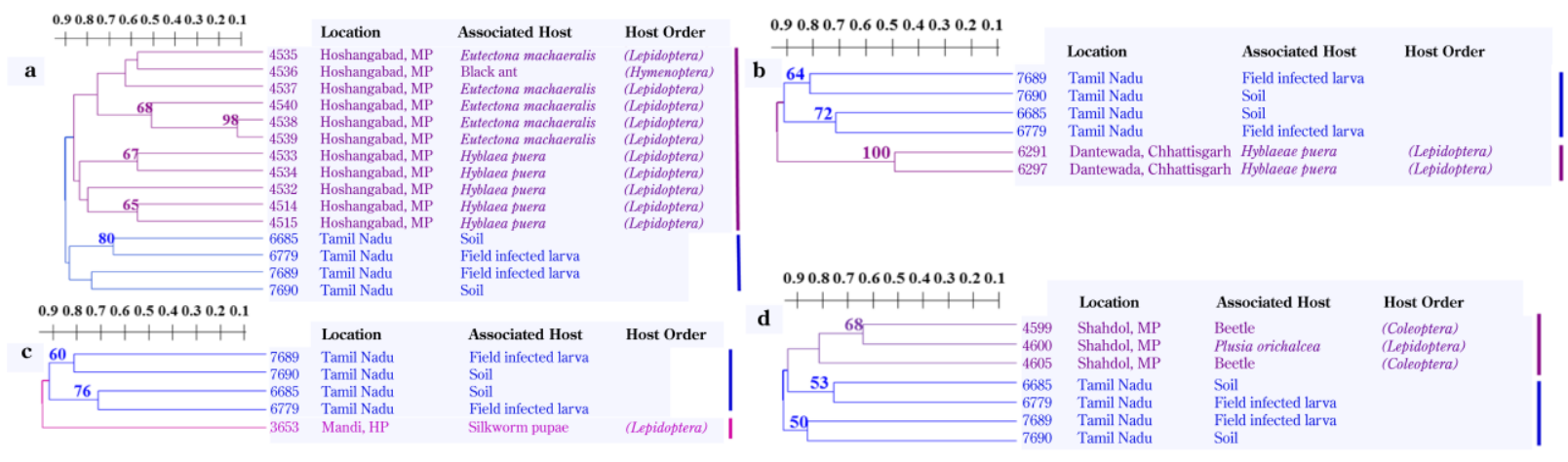

Fig. 6 - Region-wise genetic correlations of Tamil Nadu (Southern-India) with other parts of India (MP, HP and Chhattisgarh). Bootstrap values above 50\% are highlighted

The genetic groupings obtained with reduced dataset based on its original locality (MP, HP, Chhattisgarh and Tamil Nadu) and host related associations (Eutectona machaeralis vs. Plusia orichalcea) supported the previous findings that $B$. bassiana isolates exhibit higher association with their habitat and geographical location rather than host species (Bidochka et al. 2002, Wang et al. 2003, Rehner \& Buckley 2005, Devi et al. 2008, Ghikas et al. 2010). Bidochka et al. (2002) had analyzed the population structure of $B$. bassiana from the Canadian Arctic (forested and agricultural habitats) region and associated them with distinct genetic groups (three different habitats), but no any clear associations with host could be ascertained by them. Similarly, Wang et al. (2003) presented the genetic relatedness of B. bassiana isolates with geographical locality from China, Japan and USA regions. Nevertheless, in the present study we have not discussed the role of habitat type and the prevalent climatic factors like temperature, light, rainfall, salinity, etc., that should be further explored in future studies from the Indian populations.

The observed genetic diversity, except for the locus Ba01, predicts the neutral allele theory of molecular evolution with the projected evolution in the adaptive direction (Duret 2008). It signifies the random processes in interpreting genotypic diversity or structural stability in evolution with limited role of allelic variation or polymorphic nature that highlights the role of habitat where the proximity in the habitat has been related to the acquisition of new hosts (Duret 2008, Kepler et al. 2012). Similar to the finding by Meyling et al. (2009), the present study indicates no specific host target for $B$. bassiana rather a versatile host range for a particular geographical location. 
The geography-centric population structure of B. bassiana sensu stricto from India, as revealed from this study, could have useful implications in future biocontrol research on entomopathogenic fungi from India.

\section{Acknowledgments}

This work was financed by Council of Scientific and Industrial Research (CSIR), Govt. of India. The authors are thankful to the Microbial Type Culture Collection (MTCC, India) from where the cultures retrieved; Gunjan Sharma for providing her inputs in manuscript editing and useful discussions. [IMTECH Communication No. 038/2013b].

\section{References}

Avise JC. 2004 - Molecular markers, natural history, and evolution. Sinauer Associates, Sunderland, pp 684.

Bidochka M, Menzies F, Kamp A. 2002 - Genetic groups of the insect-pathogenic fungus Beauveria bassiana are associated with habitat and thermal growth preferences. Archives of Microbiology 178, 531-537.

Castrillo LA, Bauer LS, Liu H, Griggs MH, Vandenberg JD. 2010 - Characterization of Beauveria bassiana (Ascomycota: Hypocreales) isolates associated with Agrilus planipennis (Coleoptera: Buprestidae) populations in Michigan. Biological Control 54, 135-140.

Challa MM, Sanivada SK, Devi KU. 2013 - Total soluble protein profiles of Beauveria bassiana and their relationship with virulence against Helicoverpa armigera. Biocontrol Science and Technology 23, 1169-1185.

Dalleau-Clouet C, Gauthier N, Risterucci AM, Bon MC, Fargues J. 2005 - Isolation and characterization of microsatellite loci from the entomopathogenic hyphomycete, Paecilomyces fumosoroseus. Molecular Ecology Notes 5, 496-498.

Devi KU, Padmavathi J, Rao CUM, Khan AAP, Mohan MC. 2008 - A study of host specificity in the entomopathogenic fungus Beauveria bassiana (Hypocreales, Clavicipitaceae). Biocontrol Science and Technology 18, 975-989.

Devi KU, Reineke A, Reddy NN, Rao CU, Padmavathi J. 2006 - Genetic diversity, reproductive biology, and speciation in the entomopathogenic fungus Beauveria bassiana (Balsamo) Vuillemin. Genome 49, 495-504.

Duret L. 2008 - Neutral Theory: The Null Hypothesis of Molecular Evolution. Nature Education 1, 803-806.

Enkerli J, Kolliker R, Keller S, Widmer F. 2005 - Isolation and characterization of microsatellite markers from the entomopathogenic fungus Metarhizium anisopliae. Molecular Ecology Notes 5, 384-386.

Enkerli J, Widmer F. 2010 - Molecular ecology of fungal entomopathogens: molecular genetic tools and their applications in population and fate studies. Biocontrol Science and Technology 55, 17-37.

Enkerli J, Widmer F, Gessler C, Keller S. 2001 - Strain-specific microsatellite markers in the entomopathogenic fungus Beauveria brongniartii. Mycological Research 105, 1079-1087.

Felsenstein J. 1985 - Confidence limits on phylogenies: an approach using the bootstrap. Evolution 39, 783-791.

Fernandes EK, Costa GL, Moraes AM, Zahner V, Bittencourt VR. 2006 - Study on morphology, pathogenicity, and genetic variability of Beauveria bassiana isolates obtained from Boophilus microplus tick. Parasitology Research 98, 324-332.

Ghikas D, Kouvelis V, Typas M. 2010 - Phylogenetic and biogeographic implications inferred by mitochondrial intergenic region analyses and ITS1-5.8S-ITS2 of the entomopathogenic fungi Beauveria bassiana and B. brongniartii. BMC Microbiology 10, 174-188.

Haraprasad N, Niranjana SR, Prakash HS, Shetty HS, Wahab S. 2001 - Beauveria bassiana-a potential mycopesticide for the efficient control of coffee berry borer, Hypothenemus 
hampei (Ferrari) in India. Biocontrol Science and Technology 11, 251-260.

Kepler, R.M., Sung, G.H., Harada, Y., Tanaka, K., Tanaka, E., Hosoya, T., Bischoff, J.F., Spatafora, J.W. 2012 - Host jumping onto close relatives and across kingdoms by Tyrannicordyceps (Clavicipitaceae) gen. nov. and Ustilaginoidea (Clavicipitaceae). American Journal of Botany 99, 552-561.

Meyling NV, Lubeck M, Buckley EP, Eilenberg J, Rehner SA. 2009 - Community composition, host range and genetic structure of the fungal entomopathogen Beauveria in adjoining agricultural and seminatural habitats. Molecular Ecology 18, 1282-1293.

Meyling NV, Pilz C, Keller S, Widmer F, Enkerli J. 2012 - Diversity of Beauveria spp. isolates from pollen beetles Meligethes aeneus in Switzerland. Journal of Invertebrate Pathology $109,76-82$.

Nei M, Li WH. 1979 - Mathematical model for studying genetic variation in terms of restriction endonucleases. Proceedings of the National Academy of Sciences, USA 76, 5269-5273.

Oulevey C, Widmer F, Kolliker R, Enkerli J. 2009 - An optimized microsatellite marker set for detection of Metarhizium anisopliae genotype diversity on field and regional scales. Mycological Research 113, 1016-1024.

Ownley BH, Gwinn KD, Vega FE. 2010 - Endophytic fungal entomopathogens with activity against plant pathogens: ecology and evolution In: Roy HE, Vega FE, Chandler D, Goettel MS, Pell J, Wajnberg E (eds). The ecology of fungal entomopathogens. Springer, Netherlands pp 113-128.

Rehner SA, Buckley E. 2005 - A Beauveria phylogeny inferred from nuclear ITS and EF1-alpha sequences: evidence for cryptic diversification and links to Cordyceps teleomorphs. Mycologia 97, 84-98.

Rehner SA, Buckley EP. 2003 - Isolation and characterization of microsatellite loci from the entomopathogenic fungus Beauveria bassiana (Ascomycota: Hypocreales). Molecular Ecology Notes 3, 409-411.

Rehner SA, Posada F, Buckley EP, Infante F, Castillo A, Vega FE. 2006 - Phylogenetic origins of African and Neotropical Beauveria bassiana s.l. pathogens of the coffee berry borer, Hypothenemus hampei. Journal of Invertebrate Pathology 93, 11-21.

Roy HE, Vega FE, Chandler D. 2010 - The ecology of fungal entomopathogens. Springer, The Netherlands, p 204.

Takatsuka J. 2007 - Specific PCR assays for the detection of DNA from Beauveria bassiana F263, a highly virulent strain affecting the Japanese pine sawyer, Monochamus alternaturs (Coleoptera: Cerambycidae), by a sequence-characterized amplified region (SCAR) marker. Applied Entomology and Zoology 42, 619-628.

Van de Peer Y, De Wachter R. 1994 - TREECON for Windows: a software package for the construction and drawing of evolutionary trees for the Microsoft Windows environment. Computer Applications in the Biosciences 10, 569-570.

Wagner HW, Sefc KM. 1999 - IDENTITY 1.0. Centre for Applied Genetics, University of Agricultural Sciences, Vienna, Austria, http:www.boku.ac.at/zag/forsch/MANUAL.doc

Wang C, Shah FA, Patel N, Li Z, Butt TM. 2003 - Molecular investigation on strain genetic relatedness and population structure of Beauveria bassiana. Environmental Microbiology 5, 908-915.

Yao J, Zhang L, Chen X, Li Z. 2012 - A population survey of Beauveria bassiana in the microhabitat of the red turpentine beetle, Dendroctonus valens, in Chinese pine forests. Biocontrol Science and Technology 22, 1254-1267. 